\title{
PEWNIEJSZA NADZIEJA? ZACHĘTY DO ŻYCIA MONASTYCZNEGO W EPISTOLOGRAFII IV I V WIEKU**
}

Listy stanowiły zawsze szczególny rodzaj wymiany myśli. Były często nośnikiem uczuć i wartości. Nie inaczej było w przypadku listów wczesnochrześcijańskich, które swą formą nawiązywały do epistolografii łacińskiej, ale wypełnione były już zupełnie nową treścią. W pierwszym rzędzie, jako oficjalny sposób komunikacji pomiędzy biskupami i władzami, dotyczyły one spraw kościelnych, ale były także świadectwem codziennego życia chrześcijan, ich radości i problemów. Jednym z fenomenów tego okresu, który znalazł odzwierciedlenie $\mathrm{w}$ korespondencji przedstawicieli chrześcijan, było życie monastyczne i wchodzenie na jego drogę. Koniec bowiem IV wieku i wiek V to na Zachodzie okres bujnego rozwoju życia monastycznego. Pobyt św. Atanazego podczas wygnania w zachodniej części Imperium, w Trewirze i Rzymie ${ }^{1}$, a także dwa tłumaczenia na język łaciński Żywota św. Antoniego, powstałego dla grupy ascetów poza Egiptem, dokonane u początków monastycyzmu zachodniego ${ }^{2}$, z pewnością przyczyniły się do rozszerzenia jego idei w Italii, Galii i w innych częściach zachodniej części Cesarstwa³. Postacie św. Marcina z Tours, św. Hieronima, św. Euzebiusza z Vercelli i innych pociagały wielu naśladowców, którzy porzucali swoje dotychczasowe życie i podejmowali nowe, poświęcone Bogu.

${ }^{*}$ Ks. dr hab. Marcin Wysocki - adiunkt w Katedrze Patrologii Greckiej i Łacińskiej w Instytucie Historii Kościoła i Patrologii na Wydziale Teologii Katolickiego Uniwersytetu Lubelskiego Jana Pawła II; e-mail: mwysocki@kul.lublin.pl; orcid.org/0000-0001-5448-5566.

** Praca powstała w wyniku realizacji projektu badawczego o $\mathrm{nr}$ 2014/15/B/HS1/03851, finansowanego ze środków Narodowego Centrum Nauki w Krakowie.

${ }^{1}$ Por. V. Desprez, Poczatki monastycyzmu, t. 2, Dzieje monastycyzmu chrześcijańskiego do Soboru Efeskiego (431), tłum. J. Dembska, ŹM 22, Kraków 1999, 257-258.

${ }^{2}$ Por. E. Wipszycka, Wstęp, w: Św. Atanazy Aleksandryjski, Żywot świętego Antoniego. Św. Antoni Pustelnik, Pisma, red. E. Wipszycka, Warszawa 1987, 49 (= Święty Antoni, Żywot. Pisma ascetyczne, red. E. Wipszycka, ŹM 35, Kraków 2008, 68).

${ }^{3} \mathrm{Na}$ temat początków monastycyzmu na Zachodzie zob. R. Lorenz, Die Anfänge des abendländischen Mönchtums in 4. Jahrundret, ZKG 77 (1966) 1-61; M. Starowieyski, Poczatki monastycyzmu zachodniego, WST 1 (1983) 258-283; G. Penco, Storia di monachesimo in Italia: dalle origini alla fine di Medioevo, Milano 1983; J. Biarne, Les origines du monachisme en Occident, Paris 1990; G.M. Colombás, Il monachesimo delle origini, t. 1, Milano 1990, 223-246. 
W łacińskim chrześcijańskim epistolarium IV i V wieku, w listach takich postaci jak św. Augustyn, św. Hieronim, św. Ambroży czy św. Paulin z Noli, w sposób naturalny występują liczne zagadnienia związane z życiem monastycznym. Byli oni przecież jednymi z pierwszych, którzy zaszczepiali na Zachodzie idee monastyczne i w sposób praktyczny je realizowali. Jednak, co ciekawe, pośród licznych listów związanych z monastycyzmem jedynie kilka stanowi bezpośrednią zachętę do podjęcia drogi życia monastycznego. Najwięcej, bo cztery, znajdujemy w korespondencji Paulina z Noli i po jednym liście w zbiorze Augustyna i Hieronima. Warto zatem przypatrzeć się, w jaki sposób w swej korespondencji zachęcali oni tych nielicznych do podjęcia życia monastycznego, jakich argumentów używali i do kogo kierowali swe zachęty.

1. Miles Romae - miles Christi. Najliczniejszą grupą, spośród odbiorców listów, do której kierowane były zachęty do życia monastycznego, byli żołnierze. Bezsprzecznie najciekawszym przykładem są listy skierowane do Licencjusza, którego do podjęcia życia monastycznego zachęcało dwóch wybitnych przedstawicieli tego okresu: Augustyn i Paulin. W roku 396 Augustyn napisał do niego list, w którym ze zmartwieniem i z wolna traconą nadzieją ${ }^{4}$ wypominał mu, że nie oddał się jeszcze na wyłączną służbę Bożą̧ ${ }^{5}$ Licencjusz, syn wieloletniego przyjaciela i patrona Hippończyka Romaniana, był ziomkiem Augustyna, a nawet jego krewnym i wychowankiem prawdopodobnie już w Kartaginie 6 . Był także uczestnikiem swoistych rekolekcji, które miały miejsce w Cassiciacum w pobliżu Mediolanu we wrześniu 386 roku$^{7}$, których owocem i niejako zapisem są dzieła Augustyna: Contra Academicos, De vita beata i De oridine ${ }^{8}$, które były swoistym przygotowaniem do przyjęcia przez Augustyna chrztu w Mediolanie z rąk biskupa Ambrożego w Wielką Sobotę 387 roku. Hippończyk od pierwszych słów listu, będącego odpowiedzią na przesłany mu przez Licencjusza list i poemat ${ }^{9}$, wyraża głębokie rozczarowanie postawą młodzieńca, który odsuwa się i usilnie lęka się więzów mądrości, którymi jest życie poświęcone Chrystusowi, i w ten sposób pętają go kajdany spraw ziemskich ${ }^{10}$. Augustyn ukazuje swemu uczniowi, czym są owe kajdany

${ }^{4}$ Por. Augustinus, Epistula 26, 1.

${ }^{5}$ Por. tamże.

${ }^{6} \mathrm{O}$ Licencjuszu i relacji z Augustynem zob. G. Bardy, Un élève de saint Augustin: Licentius, AnTh 14 (1954) 55-79; P. Cary, What Licentius Learned: A Narrative Reading of the Cassiciacum Dialogues, „Augustinian Studies” 29 (1998) z. 1, 141-163.

${ }^{7}$ Por. Licentius, Carmen 54-55; Augustinus, Epistula 26, 3.

${ }^{8}$ Por. D. Schanzer, „Arcanum Varronis iter”: Licentius's Verse Epistle to Augustine, RÉAug 37 (1991) 110; G. Madec, L'Historicité des Dialogues de Cassiciacum, RÉAug 32 (1986) 207-231.

${ }^{9} \mathrm{Na}$ temat poematu Licencjusza zob. M. Zelzner, De carmine Licentii ad Augustinum, Diss. Breslau, Arnsberg 1915; Schanzer, „Arcanum Varronis iter”: Licentius's Verse Epistle to Augustine, s. 110-143; A.K. Clarke, Licentius Carmen ad Augustinum ll. 45 seqq., and the Easter Vigil, Studia Patristica 8, Berlin 1966, 171-175.

${ }^{10}$ Por. Augustinus, Epistula 26, 2. 
mądrości i czym są kajdany spraw ziemskich, podkreślając, że te pierwsze początkowo są nieco uciążliwe, ale ostatecznie są przesłodkie i bardzo mocne, te drugie zaś twarde i zwodniczo słodkie,

„wywołują cierpienia, a dają niepewne przyjemności. Wymagają uciążliwej pracy, a obdarzają niespokojnym spoczynkiem. Są rzeczywistością pełną nędzy i nadzieją ogołoconą ze szczęścia""11.

Licencjusz postępuje niestety według Augustyna za tymi drugimi, przyprawiając go o bolesną troskę o swe życie. W sposób szczególny tę boleść wzmaga załączony do listu poemat Licencjusza, na podstawie którego Augustyn próbuje po raz kolejny ukierunkować życie młodzieńca na drogę życia poświęconego tylko Chrystusowi, czyli drogę życia monastycznego. Hippończyk będąc świadomy swego niepowodzenia odwołuje się ostatecznie do autorytetu poezji: podejmując temat pragnienia doskonalenia się Licencjusza $\mathrm{w}$ sztuce poetyckiej wskazuje mu przykład człowieka - Paulina z Noli - który nie tylko jest wybitnym poetą, ale który przede wszystkim porzucił senatorskie godności i rodzinny majątek, i poświęcił swe życie Chrystusowi, stając się wzorem i mistrzem życia duchowego i monastycznego ${ }^{12}$. Augustyn wzywa zatem Licencjusza:

„Udaj się do Kampanii i naucz się od Paulina, tego znakomitego i świętego sługi Bożego, jak bez wahania zrzucił przepych tego świata ze swego tym szlachetniejszego, im bardziej pokornego karku, aby go poddać pod jarzmo Chrystusa, tak jak go istotnie poddał. Zażywa teraz spokoju i w swej skromności cieszy się z Chrystusem, który go prowadzi swoją drogą. Idź i naucz się, jak Bogu w hołdzie oddaje skarby swego umysłu. Zwraca Bogu dobro, które od Niego otrzymał, aby nie stracić wszystkiego, gdyby Najwyższemu nie oddał tego, co od Niego posiada"'13.

Nie wiemy, czy Licencjusz usłuchał swego nauczyciela, gdyż nie posiadamy listów Licencjusza skierowanych do Paulina. Pewne jest, że Augustyn sam polecił go Paulinowi w swym liście, w którym pisał:

${ }^{11}$ Tenże, Epistula 26, 2, PL 33, 104: „Vincula vero huius mundi asperitatem habent veram, iucunditatem falsam; certum dolorem, incertam voluptatem; durum laborem, timidam quietem; rem plenam miseriae, spem beatitudinis inanem", tłum. W. Eborowicz: Św. Augustyn, Listy (1-75), Pelplin 1983, 197.

${ }^{12}$ Por. T.J. Lienhard, Paulinus of Nola and early western monasticism with a study of the chronology of his works and an annotated bibliography, 1879-1979, Bonn 1977; A. Ruggiero, San Paolino maestro di fede e di vita, Napoli - Roma 1994.

${ }^{13}$ Augustinus, Epistula 26, 5, PL 33, 107: „Vade in Campaniam, disce Paulinum egregium et sanctum Dei servum, quam grandem fastum seculi huius, tanto generosiore, quanto humiliore cervice incunctanter excusserit, ut eam subderet Christi iugo, sicut subdidit; et nunc illo moderatore itineris sui quietus et modestus exsultat. Vade, disce quibus opibus ingenii sacrificia laudis ei offerat, refundens illi quidquid boni accepit ex illo, ne amittat omnia, si non in eo reponat a quo haec habet", thum. Eborowicz, s. 199. 
„jego syna [Romaniana - MW], naszego syna, którego imię znajdziesz w niektórych moich książkach, postanowiłem oddać w liście w Twoje ręce, abyś mu dodał otuchy, zachęcał go i pouczył - nie tyle głosem ust swoich, ile raczej przykładem swej siły"14.

Zaś Paulin, spełniając wolę Augustyna, przesłał swój list Licencjuszowi, w którym podjął próbę nakłonienia młodzieńca do wejścia na drogę życia poświęconego Chrystusowi. Wskazał przede wszystkim na przykład św. Augustyna, którego określił ojcem Licencjusza, i wezwał do naśladowania go. Argumentem, który przywołał, jest znowu owa lepsza nadzieja na przyszłość, która czeka Licencjusza, jeśli podąży za Chrystusem ${ }^{15}$. Licencjusz, który obawiał się o swą ziemską karierę, idąc za Chrystusem zostanie ustanowiony konsulem i najwyższym kapłanem ${ }^{16}$. Ostatecznie jednak Paulin sięgnął w swym liście po argument najbliższy młodzieńcowi, czyli poezję, i w 108 wersach elegijnych zachęcał go do zerwania więzów ze światem i wzięcia na siebie brzemienia Chrystusa. Zauważył, że słowa prozy mogą ranić jego uszy, dlatego postanawia prowadzić go do Pana, twórcy wszelkiego rodzaju harmonii, za pomocą metrów poetyckich. Rzym jest w nich obrazem świata doczesnego, który oferuje życie na pozór miłe i różnorakie, w rzeczywistości jednak są to tylko ułudy. Świat bowiem daje jedynie niebezpieczne, niepewne życie i zniewolenie, a jedynie złożenie nadziei w Chrystusie, służenie Mu, czyni człowieka wolnym i daje mu prawdziwe zaszczyty i pozycję. Dlatego w zakończeniu swego listu Paulin wzywał młodzieńca:

„Licencjuszu, możesz liczyć na wspaniałą pomoc krewnego i wielkiego mistrza, a wahasz się wznieść do gwiazd na tych skrzydłach? Cokolwiek byś czynił - bo niech świat nie spodziewa się mieć w tobie przyjaciela - nie oddasz się światu, duszo poświęcona Chrystusowi. Choć teraz myślisz o małżeństwie i wysokich zaszczytach, przecież kiedyś powrócisz do swego Pana. Dwaj sprawiedliwi, jak wierzę, pokonają jednego grzesznika, a braterskie modły rozproszą twe obecne ambicje. Wróć zatem tam, dokąd każe ci powrócić ojciec swym głosem, dokąd brat cię wzywa przez swe pokrewieństwo - obaj kapłani. Oni chcą ciebie przyprowadzić z powrotem do twoich dóbr, bo teraz bardzo pragniesz dóbr cudzych. Twoimi są raczej te, które zachowują władzę nad tobą. Skieruj się do nich, gorąco ich pragnij, nie trać czasu na inne" ${ }^{17}$.

${ }^{14}$ Augustinus, Epistula 27, 6, PL 33, 110: „Filium autem eius, filium nostrum, cuius etiam nomen in aliquibus nostris libris invenies, etsi ad tuae caritatis praesentiam ipse non pergeret, statueram litteris in manum tuam tradere consolandum, exhortandum, instruendum, non tam oris sono, quam exemplo roboris tui", thum. Eborowicz, s. 209. Na temat korespondencji Augustyna i Paulina zob. A.P. Muys, De briefwisseling van Paulinus van Nola en Augustinus, Hilversum 1941; P. Courcelle, Les lacunes de la correspondance entre saint Augustin et Paulin de Nole, RÈA 53 (1951) z. 3, 253-300.

${ }^{15}$ Por. Paulinus Nolensis, Epistula 8, 1.

${ }^{16}$ Por. tamże.

${ }^{17}$ Paulinus Nolensis, Epistula 8, Carmen 85-97, ed. G. Santaniello: Paolino di Nola, Le Lettere, 
Paulin w całym liście w sposób zdecydowany ukazuje wyższość powołania do życia monastycznego i oddania się całkowicie Chrystusowi. Licencjusza czeka dużo lepszy los, jeżeli pójdzie za Zbawicielem, niż ten, który może mu zaofiarować Rzym ze swymi bogactwami i tytułami w czasie służby wojskowej.

Drugi przykład nakłaniania do podjęcia służby Chrystusowi w miejsce służby wojskowej pochodzi z epistolarium św. Hieronima. W liście 145, skierowanym do niejakiego Eksuperancjusza, napisanym w Betlejem pomiędzy 397 a 399 rokiem, Hieronim wzywa go, aby porzucił służbę wojskowa, oddał się doskonalszemu życiu chrześcijańskiemu i razem ze swym bratem Kwintylianem przybył do Betlejem, aby tam prawdopodobnie prowadzić życie mnisze u boku Strydończyka. Hieronim podkreśla, że Eksuperancjusz już prowadzi życie chrześcijańskie, że

„pod płaszczem żołnierskim i strojem wojskowym wykonuje uczynki Proroków i jak człowiek wewnętrzny, który ukształtowany jest na obraz Stwórcy, przewyższa człowieka zewnętrznego"18.

Wzywa go jednak do uczynienia kroku dalej - do pozostawienia wszystkiego, stania się wolnym i podążania za Zbawicielem. Pisze do niego:

„Porzuć ciężar świata, nie szukaj bogactw, które przyrównywane są do garbów wielbłądzich. Ogołocony i lekki wzlatuj ku niebu, aby skrzydeł twoich cnót nie przygniatał ciężar złota" ${ }^{19}$.

Podkreśla jednoznacznie małość dóbr ziemskich i konieczność wyzbycia się ich, konieczność ubóstwa i złożenia swej nadziei w Chrystusie, aby mógł On uznać tak ogołoconego człowieka

„za swego bardzo mężnego nowego żołnierza, aby na spotkanie przybywającego z bardzo dalekiej krainy wybiegł z weselem Ojciec, aby ubrał w szatę, darował pierścień, ofiarował dla ciebie tuczonego woła"20.

\footnotetext{
t. I, s. 290-292: „Tanto fratre uales et praeceptore, Licenti, / Et dubitas pennis talibus astra sequi? / Quicquid agas - nam te nec speret mundus amicum - / Non deberis terrae debita Christo anima. / Tu thalamos licet et celsos mediteris honores / Nunc, olim domino restituere tuo. / Credo unum uicent iusti duo peccatorem / Et tua fraternae uota preces abigent. / Ergo redi; qua uoce parens, qua sanguine frater, / Ambo sacerdotes te remeare iubent. / Ad tua te retrahunt, nam nunc aliena petessis; / Haec mage, quae retinent regna tui, tua sunt. / Haec repete, his inhia; externis ne contere tempus", thum. Eborowicz, s. 234.

${ }^{18}$ Hieronymus, Epistula 145, ŹMT 68, 79: ,qui sub paludamento et habitu militari agat opera Prophetarum, et exteriorem hominem aliud promittentem, vincat interiori homine, qui formatus est ad imaginem Creatoris”, tłum. J. Czuj: Św. Hieronim, Listy, ŹMT 68, Kraków 2013, 79*.

${ }^{19}$ Tamże: „Proiice sarcinam saeculi, ne quaeras divitias, quae camelorum pravitatibus comparantur. Nudus et levis ad coelum evola, ne alas virtutum tuarum auri depromant pondera”, ŹMT 68, 79*.

${ }^{20}$ Tamże, ŹMT 68, 80: „ut fortissimum tyrunculum suum Christus agnoscat; ut laetus tibi de longissima regione venienti occurrat Pater; ut stolam tribuat, ut donet annulum, ut immolet pro te vitulum saginatum", ŹMT 68, 80*.
} 
Hieronim jednoznacznie podkreśla więc lepszą perspektywę przyszłości dla człowieka, który wszystko poświęci dla Chrystusa, nawet pomimo wydawałoby się zgubnego podjęcia życia w ubóstwie.

Cechami charakterystycznymi tego rodzaju listów jest ukazanie wyższości służby Chrystusowi nad służbą państwu i cesarzowi. Używana argumentacja ukazuje nadzieję na pewniejsze dobra i zaszczyty, które otrzyma się od Chrystusa za oddanie Mu życia i wyzbycie się ziemskich pragnień, dóbr i zaszczytów.

2. Nobiles Christi. Drugą grupą spośród niewielkiej ilości listów zawierających zachęty do podjęcia życia monastycznego, do której adresowane są wezwania autorów listów IV i V wieku, są ludzie bogaci, należący do wyższych klas społeczeństwa. Jedynym zachowanym przykładem takiej korespondencji są trzy listy Paulina z Noli skierowane do Apera i jego żony Amandy ${ }^{21}$. Listy te są świadectwem rodzącego się powołania do życia monastycznego i roli rodziny w tym procesie. Aper był wieloletnim przyjacielem Paulina, znanym adwokatem i zarządcą prowincji. Będąc chrześcijaninem i piastując publiczne funkcje, postanawia wycofać się z życia publicznego, aby przygotować się do podjęcia życia monastycznego.

Swiadectwem tego pierwszego okresu jest list 38. Paulina do Apera. Paulin wyraża najpierw swoją radość z wiary, która zrodziła się w sercu Apera. Wychwala, że posiada on już niezachwianą wiarę i publicznie wyznaje, że Jezus Chrystus ukrzyżowany jest Synem Bożym i Bogiem; że uznaje Go za Pana i Boga; że On żyje na wieki, aby dać ludziom nadzieję nieśmiertelności po zmartwychwstaniu umarłych ${ }^{22}$. Paulin podkreśla moc i doskonałość wiary Apera, jego dojrzałość w wierze. Stwierdza, że jest on prawdziwym naśladowcą Chrystusa ${ }^{23}$, wrogiem świata ${ }^{24}$, cierpiącym dla Chrystusa z powodu ataków wrogów Chrystusa ${ }^{25}$. Ukazuje, że wszyscy sprawiedliwi w Piśmie Świętym byli prześladowani i co należy czynić w takim przypadku, gdy ludzie nie rozumieją postępowania chrześcijan porzucających świat i światowe życie ${ }^{26}$. Taki zaś człowiek niszczy w ten sposób w sobie dumę, staje się pokorny i ubogi, napełniony prawdziwym błogosławieństwem religijnego ubóstwa $i$, tak jak w Aperze, dokonują się w nim wielkie Boże cuda ${ }^{27}$. W końcówce listu Paulin nawiązuje wprost do wydarzeń z życia Apera i wskazuje mu cel, który powinien mu przyświecać, skoro dokonał już tak wiele. Pisze:

${ }^{21}$ Por. J. Pałucki, Świeccy adresaci listów Paulina z Noli, VoxP 22 (2002) t. 42-43, 253-260; tenże, Epistolografia Paulina z Noli (353-430). Adresaci oraz okoliczności powstawania listów, w: Fructus Spiritus est Caritas. Księga Jubileuszowa Księdza Franciszka Draczkowskiego, red. M. Wysocki, Lublin 2011, 305-313.

${ }^{22}$ Por. Paulinus Nolensis, Epistula 38, 1.

${ }^{23}$ Por. tamże 38, 2.

${ }^{24}$ Por. tamże 38, 2.

${ }^{25}$ Por. tamże 38, 2-3.

${ }^{26}$ Por. tamże 38, 3-5.

${ }^{27}$ Por. tamże 38, 8 . 
„Święte i niewinne jest to, co się Bogu podoba, a nie ludziom, i dlatego rzadko, jak piszesz, odwiedzasz miasta, pokochałeś rodzinną samotność cichej wsi, bynajmniej nie dlatego, że przedkładasz odpoczynek nad pracę lub że oddalasz się od tego, co użyteczne dla Kościoła, lecz aby uniknąć hałaśliwych zgromadzeń organizowanych w kościołach, które niemal dorównują hałasowi forum. Lecz sądzę, że jest to przygotowanie się do większej służby Kościołowi poprzez mądrą decyzję poświęcenia się całkowicie świętym pouczeniom. Oddany studiom duchowym, których przyjaciółką jest samotność, formujesz i wzmacniasz w sobie codziennie Chrystusa, abyś jako jego sługa bardziej użyteczny i nauczyciel bardziej uczony, stał się bardziej godny pozycji, do której zostałeś wyniesiony z woli Bożej”28.

Paulin ukazuje więc jednoznacznie przeznaczenie i powołanie Apera. Niestety nie jest to koniec problemów na drodze do całkowitego oddania się przyjaciela Paulina życiu monastycznemu. Rodzina Apera i Amandy wraz z synami należała niewątpliwie do zamożnych. Porzucenie przez głowę rodziny spraw świeckich, a co za tym idzie zarządzania majątkiem, wymagało poważnych zmian i wyjątkowych decyzji. Dlatego też list 39. Paulin poświęca przedstawieniu teologii posiadania, rozpoczynając stwierdzeniem, że ich miłość do Chrystusa jest jego własnością ${ }^{29}$. Następnie, biorąc przykłady z życia ogrodu, z fauny i flory, ukazuje nie tylko, że posiadłości są źródłem i utrzymaniem życia ziemskiego, ale także duchowego ${ }^{30}$. To człowiek jest Chrystusowym polem, jego serce ma być uprawiane i ma się prezentować tak jak chciałby, aby prezentowały się jego posiadłości: nawodnione, uprawiane, pozbawione chwastów $^{31}$. Człowiek powinien mieć zatem staranie o swoją duszę, tak jak troszczy się o swoją ziemię. Jest bowiem nieustannie zagrożony przez różnego rodzaju niebezpieczeństwa, które Paulin przedstawia biorąc przykłady z życia wiejskiego: szkodniki, chwasty, bestie i ptaki ${ }^{32}$. Jedynie trwanie w Bogu jako winorośli pozwala przetrwać i wydać prawdziwy owoc ${ }^{33}$.

Po takim ukazaniu wartości posiadłości, a przede wszystkim ukazaniu konieczności wszczepienia się w Chrystusa i oddania się Mu całkowicie, w kolejnym - 44. liście - Paulin przechodzi do omawiania kwestii opieki nad majątkiem. Co ciekawe, w odpowiedzi na list Apera, który musiał się skarżyć na

${ }^{28}$ Tamże 38, 10, Santaniello, t. II, s. 378: ,non quod hominibus, sed quod deo placet sanctum et inncens esse, et ideo rarus, ut scribis, urbium frequentator, familiarne secretum taciti ruris adamasti, non otium negotio praeferens neque te ecclesiasticae utilitati subtrahens, sed iam pene forensibus turbis aemulos ecclesiarum tumultu et concilia inquieta declinans. Arbitror autem id ipsum maioribus ecclesiae utilitatibus praeparari, quod salubri consilio instructioni sanctae uacas et intentus studiis spiritalibus, quibus solitudo amica est, formas in te cotidie confirmasque Christum, quo et seruus utilior et magister doctior digniorem te ea in quo nutu dei positus es sedes perficias", thum. własne.

${ }^{29}$ Por. tenże, Epistula 39, 1.

${ }^{30}$ Por. tamże 39, 2.

${ }^{31}$ Por. tamże 39, 3.

32 Por. tamże 39, 4-5.

${ }^{33}$ Por. tamże 39, 6. 
konieczność podejmowania troski o dobra materialne, Paulin wyraźnie poleca, aby sprawami zarządu dobrami zajęła się Amanda, żona Apera, aby ten mógł się wyłącznie poświęcić życiu, do którego został powołany. Amanda w zastępstwie swego męża ma oddawać się sprawom ziemskim, trwając niczym utwierdzona na skale wieża wobec morskich fal ${ }^{34}$. Budowany na takiej skale dom nie runie, ona bowiem posiada niestrudzony umysł, ona przełamuje światowe fale zagrażające domostwu poprzez swe święte oddanie, dzięki któremu Aper może być zachowany od grożących mu odmętów morza, czyli świata, niczym statek zacumowany w porcie Kościoła ${ }^{35}$. Paulin zwracając się do małżonków używa znanego obrazu niszczącego morza oraz skały, która mu się przeciwstawia, jak i łodzi, która targana jest jego falami, lecz znajduje bezpieczny postój w porcie. Amanda pełniąc tak ważną rolę na duchowej drodze swego męża Apera, podejmując niejako walkę z żywiołami świata, gdy dokonuje transakcji i administruje majątkiem, nie służy jednak światu, co podkreśla Paulin, ale samemu Chrystusowi, co więcej ona naraża się dla Apera i jego całkowitego oddania Chrystusowi.

„Ona podejmuje światowe sprawy, abyś ty mógł o nich zapomnieć” - pisze Paulin do Apera - „ona zajmuje się nimi, abyś ty mógł zajmować się sprawami nieba. Ona okazuje się jako posiadająca dobra, abyś ty nie był posiadany przez świat, ale przez Chrystusa" 36 .

Jest to więc wyjątkowe dowartościowanie roli kobiety, matki, a nade wszystko żony - ona niejako sprawuje funkcję pater familias, stając się mater familias. Ona jest doskonałym wypełnieniem skrypturystycznych wzorów kobiet. Dzięki jej postawie Aper może całkowicie oddać się Bogu i dlatego Paulin, kończąc swój wywód o roli kobiety i jej wspomaganiu męża, wychwala Amandę:

„Jej wiara podwaja twoją łaskę, ponieważ «dobra kobieta jest koroną dla swego męża», a twoje zaszczyty są też jej purpurą. Dlatego kierowani łaską Pana zostaliście obleczeni zwyczajnie jednością wiary, teraz zaś oblekacie się wzajemnie dziełami cnót duchowych. Ty jesteś w Chrystusie jej głową, a ona twym fundamentem, gdyż dzięki jej pracy Twoje stopy stoją na drodze Pańskiej”37.

Paulin podkreśla więc konieczność poświęcenia się całkowicie sprawom Chrystusa i kroczenia po Jego ścieżkach, ale jednocześnie, świadom ludz-

${ }^{34}$ Por. tenże, Epistula 44, 4.

${ }^{35}$ Por. tamże.

${ }^{36}$ Tamże, Santaniello, t. II, s. 490: „Curat illa saeculi curas, ne tu cures; curat ut <caelli $>$ cures. Possidere uidetur, ne tu possidearis a Mundo et ut possidearis a Christo", thum. własne.

${ }^{37}$ Tamże, Santaniello, t. II, 492-494: „cum et illius fides gratiam tuam duplicet, quia «mulier bona corona est uiro suo», et uicissim illi honor tuus purpura est, quia temperante domini gratia simpliciter fidei unitate uestiti superinduitis uos inuicem spiritalium operatione uirtutum? Tu illi in Christo caput, et illa fundamentum tibi, cuius opera pes tuus stat in uia domini”, thum. własne. 
kich ograniczeń i konieczności, znajduje sposób w jaki można pogodzić życie poświęcone Chrystusowi z koniecznością utrzymania rodziny. Warto także zauważyć szczególną teologię małżeństwa i ważną rolę kobiety i małżonki, która przejmuje zadania mężczyzny i męża, co w świecie starożytnym było wyjątkowe, aby mu umożliwić całkowite oddanie się Bogu ${ }^{38}$. Należy podkreślić, że w myśli Paulina, także dla ludzi bogatych, posiadających majętności, otwarta jest droga do prowadzenia życia monastycznego, jak tego przykład znajdujemy w Paulinie i jego żonie Terazji, ale także - przynajmniej teoretycznie, gdyż nie wiemy o nich nic pewnego - w Aperze i Amandzie.

Pośród prawie 500 listów omawianych 4 autorów znajdujemy zaledwie 7 , które dotyczą tematyki powołania i zachęt do życia monastycznego. Skierowane są one do zaledwie trzech osób, które jednak są przykładem poważnych rozterek i problemów przy wkraczaniu na drogę życia monastycznego. Czy znaczy to, że inni problemów nie mieli? Z pewnością te trzy osoby są przykładem rozterek, przed którymi stawali adepci życia monastycznego na Zachodzie. Tu panowała zupełnie inna atmosfera od tej w Egipcie, czy we wschodniej części Imperium. Życie monastyczne nie było tak masowe i tak popularne. Ale z drugiej strony są to przykłady ludzi z wyższych sfer, przed którymi nie piętrzyły się problemy i wątpliwości związane z niskim statusem społecznym, brakiem majątku, czy zajmowanym stanowiskiem, ale raczej z tym, jak tego wszystkiego, wobec wymagań Chrystusa, się pozbyć. Na takie rozterki odpowiadają omówione powyżej listy. Niestety w zachowanych epistulariach posiadamy tylko takie przykłady osób pochodzących z wyższych sfer. Wynika to z pewnością z prostego faktu pochodzenia i pozycji nadawców listów oraz ich statusu majątkowego, które pozwalały na prowadzenie korespondencji, ale można domniemywać, że podobne problemy dotyczyły również warstw niższych, choć dla nich wstąpienie na drogę życia monastycznego mogło być traktowane jako nobilitacja i zapewnienie przyszłości.

Analiza prezentowanych listów wskazuje również na to, że wpisują się one w ustalenia dotyczące rozwoju monastycyzmu zachodniego. Lata ok. 339435 są nazywane stuleciem inicjatorów i myślicieli ${ }^{39}$. Omawiane listy są doskonałym na to przykładem - ich autorami są najwybitniejsze jednostki tego okresu; ich odbiorcy w pewien sposób szukają mistrza, kogoś kto ich ukierunkuje, albo też wskazany im został konkretny mistrz, który rozwiąże ich wątpliwości; w listach tych widać także pewnego rodzaju nieporadność i dopiero kształtowanie się idei monastycyzmu w konkretnych uwarunkowaniach naznaczonych zachodnim charakterem i temperamentem. W omawianych li-

${ }^{38}$ Por. J. Pałucki, Matżeństwo droga doskonalenia chrześcijańskiego na podstawie epistolografii św. Paulina z Noli, VoxP 32 (2012) t. 57, 469-481.

${ }^{39}$ Por. Desprez, Poczatki monastycyzmu, s. 256. 
stach ciekawe jest również to, że dwa najważniejsze, bo w sposób dosłowny zachęcające do podjęcia drogi życia monastycznego listy, są korespondencją pomiędzy osobami nieznającymi się - między Paulinem i Licencjuszem oraz między Hieronimem i Eksuperancjuszem. Zostali oni niejako postawieni wobec siebie poprzez działanie innych osób, ale jak stwierdzają w swych listach, zadzierzgnęli przez nie szczególną więź duchowej przyjaźni ${ }^{40}$.

Powyższe listy są świadectwem ukazywania lepszego, doskonalszego życia. Nie ma odejścia od świata w sposób dosłowny, a jedynie swoiste „porzucenie" świata, a przede wszystkim głęboki wymiar eschatologiczny takiej decyzji. Jest głęboka nadzieja, że za porzucenie tego, co ziemskie, oczekuje na człowieka, podejmującego życie monastyczne, nagroda, która przewyższa ziemskie dobra. W obliczu marności świata, jego trosk i problemów, ukazywana jest z pewnością lepsza nadzieja.

\section{SURER HOPE? ENCOUREGMENTS FOR TAKING UP A MONASTIC LIFE IN THE LATIN CHRISTIAN LETTERS OF THE $4{ }^{\mathrm{TH}}$ AND $5^{\mathrm{TH}}$ CENTURY}

\section{(Summary)}

The turn of the $4^{\text {th }}$ and $5^{\text {th }}$ centuries is a period of exuberant development of a monastic life in the West. This fact was also reflected in the correspondence of the authors of this period (Ambrose, Augustine, Jerome and Paulinus Nolensis of Nola), who are considered to be the fathers of the Western monasticism. Many people entered the path of life devoted to Christ voluntarily and without dilemmas, but there were also those who were encouraged to make this decision and yet they felt some resistance. Of this we can also find testimonies in the letters of the authors mentioned above. Among their nearly 500 letters, we find only seven that relate to the theme of calling and encouragement to the monastic life. They are directed to only three people (two soldiers and wealthy married couple), which, however, are an example of serious dilemmas and problems with entering the path of monastic life. The authors show in their letters arguments for taking up monastic life and ways of its implementation. The letters show a better and more perfect life. In letters there is no call for leaving the world in a literal way, but only a peculiar "abandonment" of the world, and above all a profound eschatological dimension of such a decision. There is a deep hope that for abandoning what is earthly, a reward that transcends earthly goods awaits for a man who undertakes a monastic life. In the face of the vanity of the world, its worries and problems, certainly a better hope is shown in the encouragements of the letters.

Key words: Augustine, Jerome, Paulinus of Nola, letters, hope, monastic life, world, richness, military service.

${ }^{40}$ Por. J. Pałucki, Eklezjotwórcza funkcja przyjaźni w nauczaniu Paulina z Noli, StWł 14 (2012) 88-104. 
Słowa kluczowe: Augustyn, Hieronim, Paulin, listy, nadzieja, życie monastyczne, świat, bogactwo, służba wojskowa.

\section{BIBLIOGRAFIA}

\section{Źródła}

Augustinus, Epistulae, CSEL 34/1-2, 44, 57, ed. A. Goldbacher, Vienna 1895-1911, tłum. W. Eborowicz: Św. Augustyn, Listy (1-75), Pelplin 1983.

Hieronymus, Epistulae, t. 1-5, wyd. łacińsko-polskie, tekst łac. i oprac. H. Pietras, thum. J. Czuj, oprac. M. Ożóg: Św. Hieronim, Listy, ŹMT 54, 55, 61, 63, 68, Kraków 2010-2013.

Paulinus Nolensis, Epistulae, ed. G. Santaniello: Paolino di Nola, Le lettere, Testo latino con traduzione italiana a cura di G. Santaniello, t. 1-2, Nola 1992.

\section{Opracowania}

BARDy G., Un élève de saint Augustin: Licentius, AnTh 14 (1954) 55-79.

Biarne J., Les origines du monachisme en Occident, Paris 1990.

CARY P., What Licentius Learned: A Narrative Reading of the Cassiciacum Dialogues, „Augustinian Studies” 29 (1998) z. 1, 141-163.

Clarke A.K., Licentius Carmen ad Augustinum ll. 45 seqq., and the Easter Vigil, Studia Patristica 8, Berlin 1966, 171-175.

Colombís G.M., Il monachesimo delle origini, t. 1, Milano 1990, 223-246.

Courcelle P., Les lacunes de la correspondance entre saint Augustin et Paulin de Nole, RÈA 53 (1951) z. 3, 253-300.

Desprez V., Poczatki monastycyzmu, t. 2, Dzieje monastycyzmu chrześcijańskiego do Soboru Efeskiego (431), thum. J. Dembska, ŹM 22, Kraków 1999.

LiEnhard T.J., Paulinus of Nola and early western monasticism with a study of the chronology of his works and an annotated bibliography, 1879-1979, Bonn 1977.

Lorenz R., Die Anfänge des abendländischen Mönchtums in 4. Jahrundret, ZKG 77 (1966) 1-61.

Madec G., L'Historicité des Dialogues de Cassiciacum, RÉAug 32 (1986) 207-231.

Muys A.P., De briefwisseling van Paulinus van Nola en Augustinus, Hilversum 1941.

PAŁUCKi J., Eklezjotwórcza funkcja przyjaźni w nauczaniu Paulina z Noli, StWł 14 (2012) 88-104.

PaŁucki J., Epistolografia Paulina z Noli (353-430). Adresaci oraz okoliczności powstawania listów, w: Fructus Spiritus est Caritas. Księga Jubileuszowa Księdza Franciszka Draczkowskiego, red. M. Wysocki, Lublin 2011, 305-313.

PAŁucki J., Matżeństwo droga doskonalenia chrześcijańskiego na podstawie epistolografii św. Paulina z Noli, VoxP 32 (2012) t. 57, 469-481.

PaŁucki J., Świeccy adresaci listów Paulina z Noli, VoxP 22 (2002) t. 42-43, 253-260.

Penco G., Storia di monachesimo in Italia: dalle origini alla fine di Medioevo, Milano 1983.

Ruggiero A., San Paolino maestro di fede e di vita, Napoli - Roma 1994.

SCHANZER D., ,Arcanum Varronis iter”: Licentius's Verse Epistle to Augustine, RÉAug 37 (1991) 110-143.

Starowieyski M., Poczatki monastycyzmu zachodniego, WST 1 (1983) 258-283.

Wipszycka E., Wstęp, w: Św. Atanazy Aleksandryjski, Żywot świętego Antoniego. Św. Antoni Pustelnik, Pisma, red. E. Wipszycka, Warszawa 1987, 31-54 (= Święty Antoni, Żywot. Pisma ascetyczne, red. E. Wipszycka, ŹM 35, Kraków 2008, 43-74). 
Zelzer M., De carmine Licentii ad Augustinum, Diss. Breslau, Arnsberg 1915.

Zelzer M., Vescovi e pastori alla luce delle lettere ambrosiane, w: Vescovi e pastori in epoca teodosiana, II, SEA 58, Roma 1997, 559-568. 